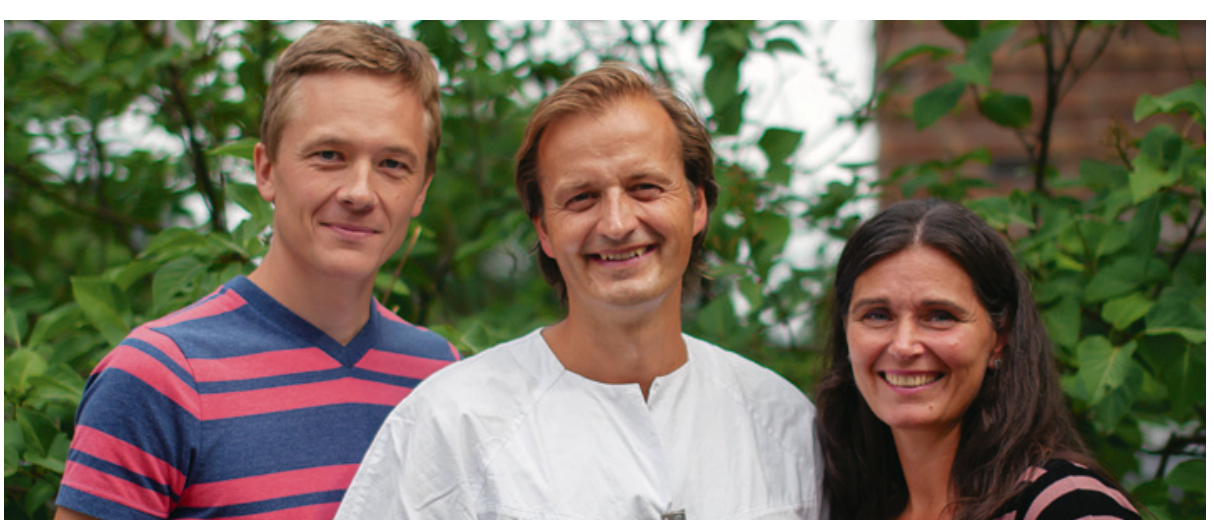

Førstefatterne Magnus Løberg (t.v.) og Mette Kalager (t.h.) og sisteforfatter Michael Bretthauer. Foto: Dagrun K. Gjøstein

\title{
Ikke mer tarmkreft etter adenomfjerning
}

Risikoen for å dø av tarmkreft er ikke høyere hos pasienter som har fått fjernet kolorektale adenomer enn i normalbefolkningen.

Om lag 25\% av norske 60-åringer har adenomer i tykktarm og endetarm. Adenomer er polypper som kan utvikle seg til kolorektal kreft. De kan fjernes ved koloskopi. Det har til nå vært enighet om at pasienter med adenomer har økt risiko for å utvikle flere adenomer, som kan utvikle seg videre til kolorektal kreft. Internasjonale retningslinjer anbefaler derfor jevnlige kontrollkoloskopier for dem som har fått fjernet adenomer. Det finnes imidlertid få store studier med tilstrekkelig lang oppfølgingstid som kvantifiserer risikoen for kreft hos pasienter som har fătt fjernet et adenom.

Forskere fra Universitet i Oslo har nå publisert en artikkel i New England Journal of Medicine hvor de presenterer resultater fra en studie om dødelighet av kolorektal kreft hos 40000 norske pasienter som fikk fjernet adenomer ved koloskopi i perioden 1993-2007.

Etter en median oppfølgingstid på 7,7 år (maksimalt 19 år) hadde 1273 adenompasienter fått kolorektal kreft og 398 var døde av sykdommen. Adenompasientene hadde ikke høyere dødelighet av kolorektal kreft enn normalbefolkningen (standardisert mortalitetsrate 0,$96 ; 95 \% \mathrm{KI} 0,87-1,06)$. Pasienter med høyrisikoadenomer, dvs. villøst vekstmønster, grov dysplasi eller flere adenomer, hadde økt dødelighet av kolorektal kreft - 242 observerte dødsfall, mot 209 forventede (standardisert mortalitetsrate 1,$16 ; 95 \% \mathrm{KI} 1,02-1,31$ ) - mens pasienter med lavrisikoadenomer hadde lavere dødelighet - 141 observerte dødsfall, mot 189 forventede (standardisert mortalitetsrate 0,75 ; $95 \%$ KI 0,63-0,88).

- Vår studie tyder på at risikoen for kolorektal kreft hos pasienter med adenomer er betydelig lavere enn tidligere antatt, sier førsteforfatter Magnus Løberg. - Nye norske retningslinjer anbefaler kontroll med koloskopi hvert tredje eller hvert femte år etter fjerning av adenomer. Slike kontroller utgjør en raskt økende andel av alle koloskopier, og mange sykehus har ikke kapasitet til å undersøke pasientene innenfor tidsfristene som anbefales. Våre funn antyder at kontrollene ikke trenger å skje så hyppig som i dag, sier Løberg.

- Vi planlegger nå en stor randomisert studie med økte intervaller mellom kontrollene for å se om dette påvirker dødelighet og forekomst av tarmkreft. Dersom man kan redusere antall undersøkelser, vil dette være positivt med tanke på mindre komplikasjonsrisiko for pasientene og lavere ressursbehov for helsevesenet, sier professor Michael Bretthauer, som er sisteforfatter av artikkelen.

\section{Forskningsgruppe for klinisk effektforskning}

Forskerne bak studien kommer fra Forskningsgruppen for klinisk effektforskning ved Institutt for helse og samfunn ved Universitetet i Oslo og Avdeling for transplantasjonsmedisin, Oslo universitetssykehus. Gruppen jobber med store kliniske studier, epidemiologi og metodeutvikling innenfor fordøyelsessykdommer, mammografi og kreftforebygging. De samarbeider tett med Sørlandet sykehus, Sykehuset Telemark, Harvard School of Public Health og Karolinska institutet. Gruppen leder nettverket Klinisk effektforskning i gastroenterologi i Helse Sør-Øst og er en del av det nyopprettede KG Jebsen senter for tarmkreft ved Oslo universitetssykehus/Universitetet i Oslo.

\section{Hanne Støre Valeur}

Tidsskriftet

\section{Litteratur}

1. Løberg M, Kalager M, Holme $O$ et al. Long-term colorectal-cancer mortality after adenoma removal. N Engl J Med 2014; 371: 799-807.

Publisert først på nett.
Ordforklaringer

Adenom: En type polypp i tykk- eller endetarm som kan utvikle seg til kolorektal kreft. De færreste adenomer utvikler seg til kreft, men de fleste tilfeller av kolorektal kreft oppstår fra adenomer. Adenomer kan fjernes med polyppektomi ved koloskopi.

Polyppektomi: Fjerning av polypper ved koloskopi. En stålslynge føres gjennom koloskopet og træs over polyppen, strammes til og tilføres elektrisk strøm for å applisere varme og skjæring. Polyppen sendes til histologisk undersøkelse for klassifisering av type, dysplasigrad og vekstmønster.

Klinisk effektforskning (clinical effectiveness research): Forskning på effektivitet av kliniske intervensjoner (terapeutiske, diagnostiske, helsetjenester osv.) ved hjelp av kliniske studier (ofte randomiserte studier) eller observasjonsstudier. Skal svare på spørsmålet: «Hva hjelper, hva hjelper ikke?»

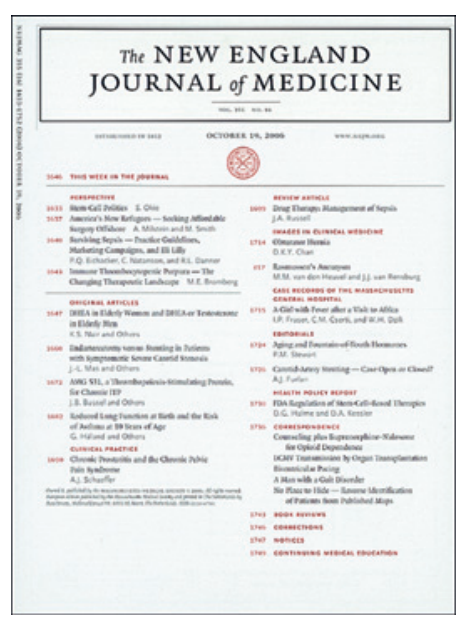

Artikkelen ble publisert 27.8. 2014 i New England Journal of Medicine, som er et av de mest velrenommerte internasjonale medisinske tidsskriftene. 